\title{
CORPORATE SOCIAL RESPONSIBILITY AS A DETERMINANT OF EMPLOYEE LOYALTY AND BUSINESS PERFORMANCE
}

\author{
- Andelka Stojanovic, Isidora Milosevic, Sanela Arsic, Snezana Urosevic, \\ Ivan Mihajlovic
}

\begin{abstract}
The paper presents the results of an international research on Corporate Social Responsibility (CSR) conducted in post-transitional countries in Europe. The aim was to investigate the recognition level of the efforts in companies toward CSR activities by employees and their influence on perception and identification with those activities. It was expected that employees with a higher level of CSR awareness would show a greater level of loyalty and identification with the company and, therefore, perform their activities better. A number of significant issues were investigated, i.e. the purpose of CSR implementation, CSR activities in companies, barriers for CSR implementation, employee loyalty, and the performance of companies, along with how these factors are interconnected. CSR was accessed from the point of view of employees through a questionnaire, after which the proposed conceptual model and hypothesis were tested using SEM methodology. The results point out that a clearly defined purpose of implementing CSR can contribute positively to appropriate CSR activities and overcoming the barriers that can occur during implementation. In addition, statistical evidence was gathered showing that CSR activities significantly influence employee loyalty, thus more commitment from employees to the company. Finally, the findings indicate that the greater the loyalty of employees, the greater the performance and competitiveness of the company. The presented results can be very significant for decision-makers and researchers, as they highlight the specificity of CSR and can be used for creating appropriate business strategies that introduce and implement CSR in business operations in order to increase competitiveness and overall company results.
\end{abstract}

Keywords: Corporate Social Responsibility, employees, business performance, competitiveness JEL Classification: M14, J20, J24

Received: December, 2019

1st Revision: May, 2020

Accepted: May, 2020

\section{INTRODUCTION}

In recent years, CSR has become a widely discussed corporate and academic theme. Businesses have a certain responsibility for the impact they make on society, considering that a firm's long- 
term survival depends on many interrelated factors. Thus promoting CSR has become seen as a necessity in regulating business operations. Since companies operate in a tough competitive environment, in decision making managers should take into consideration a number of trade-offs between, on the one hand, short-term profits and economic interests, and, on the other, longterm success through investments in CSR, the benefits of which may not be readily and directly measurable (Dos, 2017). The inclusion of CSR in business practice is more than a trend. It is a necessity for all companies that seek sustainable development as a prerequisite in their business strategies (Thao et al., 2019).

Nowadays, the predominant apprehension regarding CSR is related to the voluntary integration of social, environmental and stakeholder issues in business operations (Branco \& Rodrigues, 2006). Many research studies have been conducted in economically developed countries, although only a limited number of studies on CSR have taken place in transitional and post-transitional countries (Fifka \& Pobizhan, 2014). In countries with fast economic growth (Wu, 2013), or in those with economic systems in the process of transition and adaptation to new legislation, new business practices, and the multinational market, companies may have serious problems understanding CSR and its role in sustainable business models (Stoian \& Zaharia, 2012; Doh et al., 2015; Amodu, 2018; Ling, 2019). Also, researchers have shown that national culture values have a significant impact on the attitudes over the organizational culture (Taras et al., 2011). Taking all these factors into consideration, the integration of CSR into an organizational culture should not be ignored in research.

With the recognition of the lack of studies that show employees as targeted stakeholders in assessing the CSR impact, lately the amount of research on this topic has increased (Lee et al., 2013). Many studies show that employees relate to the specific CSR activities of companies, and consequently commitment and productivity is enhanced (Fortier, 2013; Vlachos et al., 2014; Lim \& Greenwood, 2017). Also, a notable connection between positive attitudes of employees toward socially responsible policies toward employees and their perception of the success of the company has been made clear in an number of surveys (Ali et al., 2010).

The motivation for this research is the assumption that in post-transitional European countries in particular there is still little familiarity with this issue among stakeholders. There is a need for the structuring of a proper research framework that can be used in several companies or countries. It is important to investigate a group of factors concerning the purpose of the implementation of CSR and its activities in companies, barriers to implementation, employee loyalty, company performance of companies, as well as how all these issues are interrelated.

The first section of the paper offers a brief introduction to CSR, with the second providing a theoretical base for research model development encompassing findings from the most recent publications on the topic. The third section describes the objectives and methodology of the research. In the fourth section, the results of research are presented, followed by a discussion and conclusion.

\section{THEORETICAL BACKGROUND}

Since Friedman (1970) defined the purpose of business as the use of resources in order to in- 
crease profit with respect to private property, the open market, and free competition without fraud, many authors have based their research on proving or disproving this view (Porter \& Kramer, 2011; Chen \& Gavious, 2015). Friedman also stated that CSR activities represent an unnecessary investment of the money of shareholders, and that social responsibility should be the personal choice of individuals, not a business issue (Thao et al. 2019).

Freeman \& Liedtka (1997) introduced the concept of Stakeholder Capitalism, the theory that capital is requisite but "Great companies arise in part out of a shared sense of purpose among employees and management." This puts a new light on the topic of CSR. In the 2010s, more attention was devoted to research that focuses on the interests of owners, managers, and consumers (Panwar et al., 2014; Alhouti et al., 2016; Öberseder et al., 2017). Porter \& Kramer see an opportunity for innovation if a greater focus is placed on the stakeholders' needs, a situation which can lead to an increased competitive advantage (Porter \& Kramer, 2006; Calabrese et al., 2013).

A significant number of researchers have dealt with the relationship between employees and CSR activities, with many concepts and scales for measuring CSR effects having been developed (Hanzaee \& Rahpeima, 2013). Dumitrescu \& Simionescu (2015) used empirical analyses based on accounting measures to determine company financial performance (Return on Assets (ROA) and Return on Equity (ROE)) related to CSR. Besides increasing revenues, other financial benefits of CSR have been observed through costs of production and equity reduction (Porter \& Kramer, 2006; Matthiesen \& Salzmann, 2017).

Calabrese et al. (2013) proposed a two-dimensional model for measuring the alignment between a company's CSR commitment and the stakeholders' perception of this alignment. The efforts of companies and values which stakeholders attribute to these efforts are also emphasized as an important relationship. This model enables managers to rate the effectiveness of their CSR actions and to make decisions about the type and quantity of CSR engagement.

It is often forgotten that a company's performance should not be evaluated through profit only. One very important direction of research has been the level of identification of employees with the organization as a result of continuous investment in CSR, the inclusion of employees in CSR activities, and their pride in organizational affiliation (De Roeck et al., 2016).

Some studies differentiate between the employees' feelings about CSR activities and real changes in their performance and engagement (Houghton et al., 2009; Vlachos et al., 2014). Results from these types of studies show that the involvement of a company in CSR can motivate employees to take part in CSR activities and to initiate commiftment, but CSR performance was not linked to increasing job performance.

A strong corporate culture and expressed commitment to CSR can represent a way companies can influence the trust and loyalty of employees, consumers and the general public, forming a solid basis for long-term sustainability (Grover et al., 2019). By satisfying the needs of employees and strengthening their identification with the company, the creative climate is raised, i.e. a climate favorable for innovations and problem-solving is fostered (Brammer et al., 2014).

This study proposes that the level of awareness of employees toward activities companies undertake to fulfill the needs of society such as investments in environmental protection, improving 
usage of resources, and empowering human resources have a positive influence on employee loyalty and on company performance in general. Accordingly, the following text will describe each of the four important factors correlated to the CSR activities of the company, influencing the overall business performance of the company.

\subsection{Purpose of implementing CSR}

Positive attitudes of employees toward the purpose of implementing CSR represent the first step in successfully establishing a new business concept. The implementation of CSR activities, however, influences costs. Accordingly, managers in the process of making decisions regarding social responsibility must take into account the benefits that can be gained for the company. The motivation of managers arises from striving to maximize business outcomes. At the same time, however, sometimes forsaking strategies to increase short-term profit to attempt to insure higher future incomes is more efficacious (Dare, 2016). A great deal of criticism has been made of the use of CSR for business interests as a strategic marketing tool, as well as of the fact that CSR can be utilized in an unethical way (Prasad \& Holzinger, 2013).

On the other hand, besides improving the image of the company and the loyalty of consumers, managers can find motivation in increasing attractiveness of the company for new employees (Turker, 2009; Tkalac Verčič \& Sinčić Ćorić, 2018). By increasing the company’s capabilities and competences through various CSR activities in which employees can take part, more positive attitudes toward companies are also expected among stakeholders (Korschun et al., 2014). The differences between the expected and received outcomes that can occur in the CSR implementation can diminish positive attitudes toward CSR and cause certain issues. Barriers to the implementation of CSR arise from the lack of knowledge of the necessity of introducing environmental, social and stakeholder issues in business operations. This study proposes that the overcoming of limitations should be influenced by CSR implementation. Regarding the considerations from above, two research hypotheses can be proposed:

H1 - An adequate recognition of the purpose of implementing CSR has a positive influence on the selection of the proper CSR activities in companies.

$\mathrm{H} 2$ - An adequate recognition of the purpose of implementing CSR has a positive influence on overcoming barriers for the implementation of CSR.

\subsection{CSR activities}

For doing business in a sustainable way, managers should constantly develop knowledge and comprehension of the process among employees. The inclusions of employees in the decision making process and introducing the actions on empowering the workforce are also CSR activities that should increase commitment and motivation in achieving the goals of a company (Galbreath, 2010). Among the activities, there are three directions: activities concerning employees themselves, activities stimulating general well-being and social issues, and environmental activities (Lee et al., 2013). Considering that CSR activities influence directly employees' operations as well as indirectly the well-being of their families, the positive relationship of companies' commitment in this area and employees' loyalty is expected. 
The authors proposed the implementation of CSR through human resource development (Fenwick \& Bierema, 2008). However, some studies showed that managers, although they have CSR in business strategies, invest very little effort in education, training and making a work and life balance of their employees (Garavan et al., 2010). According to this, the following hypothesis can be defined:

H3- CSR activities within companies have a positive influence on the loyalty of employees.

\subsection{Barriers for implementing CSR}

Barriers for implementing CSR have not been throughly examined in literature. Generally speaking, the focus of researchers is on resource limitations such as financial, human and time (Sweeney, 2007). Barriers can be divided into internal factors, which refer to the lack of knowledge, lack of leadership, inadequate CSR culture, lack of resources and motivation, and external factors which refer to non-existence of governmental support, lack of public support and underdeveloped mandatory regulation (Yeh et al., 2014). According to this, the following hypothesis can be defined:

H4 - The existence of barriers for the implementation of CSR does not have a positive influence on loyalty of employees.

\subsection{Loyalty of employees}

Many researchers support the belief that engaging with employees on a more personal level builds a stronger commitment to the internal reputation of their organization (Fortier, 2013; Gill, 2015; Su \& Swanson, 2019). In order to achieve the better understanding of CSR, studies concerning the influence of CSR activities on positive emotion and loyalty of employees are often conducted by psychologists, human resource (HR) management and organizational behavior (OB) theorists (Rupp et al. 2013; Onkila, 2015; Gürlek \& Tuna, 2019). Managers can strategically direct CSR activities to reinforce the work performance of employees. Employees react differently to those actions. They can see CSR as an honest attempt to demonstrate the true value of the company (intrinsic CSR practice) or as an intention of the company to gain something in return (extrinsic CSR practice) (Story \& Neves, 2015).

Behrend et al. (2009) proved in their research that the reputation of a socially responsible company is more attractive for job applicants because their perception of organizational prestige has a positive impact on their motivation for job-seeking rather in that company than the other one.

The employees' perception of behavior of the company influences their everyday work behavior. If the company shows an irresponsible or indifferent attitude to issues that are not directly aimed at making a profit, employees will probably develop negative work habits and will not have positive attitudes toward the company. High organizational justice and ethics make employees feel safe and satisfied in their work (Brammer et al., 2007). Employees feel a higher level of loyalty to the company that invests in training and education because of double benefits- personal growth and better work performance (Jia et al., 2019). The loyal employee is very valuable because through personal identification with the company, he/she shows more commitment in performing a job and thus fulfills the goals and ameliorates the company's performance (Ali et 
al., 2010). According to that, the next hypothesis can be proposed:

H5-The loyalty of employees has a positive influence on overall performance of the company.

\subsection{Business Performance}

Business performance is the term with a very complex and specific context. Quantitative performances are measurable through financial and economic measures. Some authors have assessed the impact of CSR activities based on investments in CSR and financial return using different accounting indicators only (López et al., 2007). Qualitative performances can not be easily measured but those can be very representative indicators of sustainable development of the company. Company's investments in the CSR directly benefit the company since it builds a positive reputation that ensures a long-term differentiation of the company in relation to competition (Melo \& Garrido-Morgado, 2012).

The notion of performance depends on perspective. Accordingly, what can be estimated as good performance in one perspective can be estimated as very low performance in another. Measurement of performances is more complicated when viewpoints of different stakeholders are considered.

Performances in some areas can be overlooked but just those can be crucial for the future existence of the company. To avoid the omission of some important issues in measuring performances, some authors have proposed the use of measurement tools. Most of these tools present a comprehensive set of performance measures that help managers to set the parameters in critical areas such as: financial perspective (how the firm seems to shareholders); customer perspective (how customers perceive the firm); internal business perspective (what the firm should emphasize); innovation and learning perspective (if the firm can continue to improve and create value) (Crowther \& Aras, 2008). Employees can also have opinions on those performances measured from their point of view.

According to all five factors and the proposed hypotheses introduced in the previous text, the questionnaire was developed, including the adequate groups of questions for each of the factors. Also, based on the set of proposed hypotheses, a conceptual model was developed, which consists of the 5 latent variables (factors), and 38 observing variables (groups of questions), as shown in Figure 1.

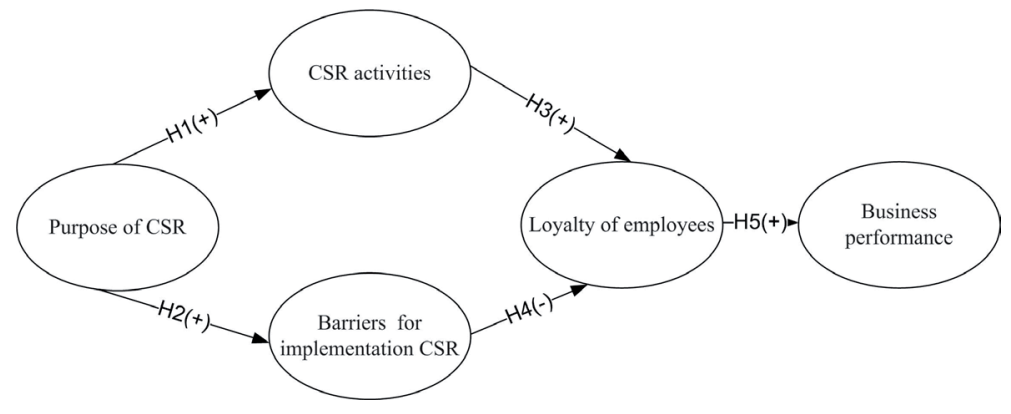

Fig. 1 - Conceptual model. Source: own research 


\section{RESEARCH OBJECTIVE, METHODOLOGY AND DATA}

The aim was to investigate the factors influencing the business performance that directly or indirectly derives from the implementation of CSR activities. In the research presented, the corporate social responsibility has been accessed from the point of employees' perception. The level of company effort recognition in CSR activities, barriers to CSR implementation as well as the influence of these factors on employees' identification with the company's values and consequently on business results, were explored.

The research on this topic was initiated by the Academic Entrepreneurship and Innovation Network of South-Eastern European Universities (The RESITA Network), the academic network consisting of 16 universities from Southeast Europe (Bulgaria, Romania, Northern Macedonia, Albania, Montenegro, Bosnia and Herzegovina, Croatia and Serbia). Subsequently, the ideas of this network, especially the CSR research, were expanded also to new partners from Russia. Until now, the data has been collected from Russia, Bulgaria and Serbia. In this paper, part of the collected data has been presented.

The data collection was conducted through questioning employees independently of the company industry, ownership type, or size. The questionnaire was developed from surveys with a similar topic (Lee et al., 2013; Reverte et al., 2016) and adjusted for this research (Appendix 1). Likert's five-degree scale was used to express the opinion of respondents. The questionnaire consisted of two groups of questions. The first group of questions relates to the demographic characteristics of respondents (gender, age, level of education, position in the company, years of service, etc.). The second group of questions is related to the general knowledge and attitude of respondents towards corporate social responsibility. In addition, within this group of questions, the influence of key parameters on the business performance of companies that implement CSR is investigated, which included all related elements of the business.

The study was conducted during the period from 2017 to 2018. The tested population included employees in the public sector (including educational and research institutions as well as cultural institutions) and employees in private companies (manufacturing and service companies of different range) that foster some form of social responsibility.

The advantage of using a questionnaire is that it provides anonymity of the respondents and confidentiality of data as well as the total standardization of collected data. The survey covered a population of 450 respondents; of which 411 filled the questionnaire form properly, which represents $91.33 \%$ of the total number of distributed questionnaires. In defining the sample, the recommendation that the minimum sample size would be at least 10 times the number of free model parameters was applied (Raykov \& Marcoulides, 2006), so it can be considered that sample is representative of the population in which the study was conducted. Such a high level of total response rate can be explained by using personal interviews with employees instead of carrying out an online or e-mail survey. Demographic characteristics of the sample are as follows.

Concerning the age structure, most respondents belong to the age group 26-35 years, 43.7\%, then $46-55,36-45$ and $18-25$ with $18.3 \%, 16.9 \%$, and $13.4 \%$ respectively. $54.9 \%$ of respondents were female. $47.9 \%$ of respondents were workers, $35.2 \%$ have a position of headworks and $13.4 \%$ were supervisors. CEOs and high positioned managers have not been part of the research since 
they, as decision-makers have a different perspective of dealing with CSR. $32.4 \%$ of respondents had a BSc level of education, $25.4 \%$ had a diploma of vocational education and $20.4 \%$ had an MSc level of education.

To analyze the proposed conceptual model, SEM methodology (Structural Equation Modeling) was used, in the software LISREL v. 8.8. Testing of measurement and structural models as well as hypotheses were performed using two-step structural equation modeling approaches first to analyze the constructs' reliability and then to explore the structural relations between them.

\section{RESULTS AND DISCUSSION}

The validity of the model was estimated using a confirmatory factor analysis (CFA), which resulted in the indices of the model fit $\left(\chi^{2} / \mathrm{df}=1.23\right.$; CFI $=0.95$; IFI $=0.95$; NNFI $=0.95$; NFI $=0.85 ; \mathrm{RMR}=0.082 ; \mathrm{RMSE}=0.041)$, and which are in accordance with the recommended values (Udo et al., 2010).

Also based on the confirmatory factor analysis, the convergent validity of the model was tested. As shown in Table 1, all load factor indicators with adequate statistical significance $(\mathrm{p}<0.01)$ are approximately 0.50 , indicating that the validity of the convergence was achieved. This suggests that the indicators used in this study adequately represent the concepts to which they refer. The coefficient of internal consistency Cronbach's $\alpha$ also indicates the fulfillment of conditions of the convergent validity, with a total value of 0.827 . All values for each of the groups of questions regarding all five factors are shown in Table 1 in order to indicate that the requirements of internal consistency are fulfilled (Milošević et al., 2015).

Tab. 1 - Confirmatory Factor Analysis. Source: own research

\begin{tabular}{|l|l|l|l|l|l|}
\hline Construct & $\mathrm{n}$ & $\begin{array}{l}\text { Standardized } \\
\text { Regression } \\
\text { Weights }\end{array}$ & t-value & $\begin{array}{l}\text { Squared mul- } \\
\text { tiple correla- } \\
\text { tions }\end{array}$ & $\begin{array}{l}\text { Cronbach's } \\
\text { alpha }\end{array}$ \\
\hline F1: Purpose of CSR & 5 & $0.44-0.67$ & $4.68-7.65$ & $0.19-0.45$ & 0.665 \\
\hline F2: CSR activities & 5 & $0.35-0.88$ & $3.87-11.65$ & $0.12-0.77$ & 0742 \\
\hline $\begin{array}{l}\text { F3: Barriers for CSR } \\
\text { implementation }\end{array}$ & 7 & $0.42-0.69$ & $4.39-8.07$ & $0.18-0.48$ & 0.787 \\
\hline $\begin{array}{l}\text { F4: Loyalty of em- } \\
\text { ployees }\end{array}$ & 12 & $0.55-0.77$ & $6.86-10.52$ & $0.28-0.59$ & 0.848 \\
\hline $\begin{array}{l}\text { F5: Business perform- } \\
\text { ance }\end{array}$ & 9 & $0.58-0.79$ & $7.33-9.88$ & $0.32-0.63$ & 0.874 \\
\hline
\end{tabular}

The structural analysis is conducted in the next step of the research provided that the fitting parameters of the SEM model are at a satisfactory level and that they fulfill the validity terms of the concepts. Figure 2 depicts $\beta$ coefficients presented above the line, and t-values presented below the line. The path analysis of the SEM model depicted in Figure 2 and in Table 2 show that all hypotheses can be accepted. 


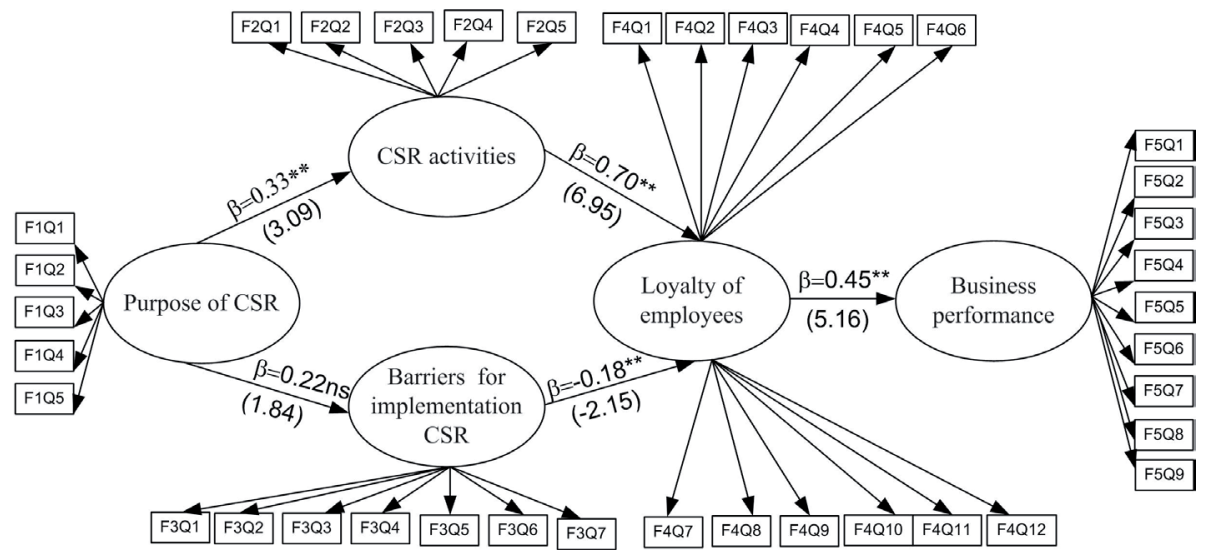

Fig. 2 - Structural model. Source: own research

(Note: ${ }^{* *} p<0.001,{ }^{*} p<0.05$, ns-non-significant)

Tab. 2 - Path Coefficients and t-Values of the Hypothesis. Source: own research

\begin{tabular}{|l|l|l|l|}
\hline Hypothesis testing & $\begin{array}{l}\text { Standardized regression } \\
\text { coefficient }\end{array}$ & $\begin{array}{l}\text { Critical ratio } \\
\text { (t-value) }\end{array}$ & Result \\
\hline $\begin{array}{l}\text { (H1) Purpose of CSR } \rightarrow \text { CSR } \\
\text { activities }\end{array}$ & $0.33^{* *}$ & 3.09 & Supported \\
\hline $\begin{array}{l}\text { (H2) Purpose of CSR } \rightarrow \text { Bar- } \\
\text { riers for CSR implementation }\end{array}$ & $0.22 \mathrm{~ns}$ & 1.84 & Not supported \\
\hline $\begin{array}{l}\text { (H3) CSR activities } \rightarrow \text { Loyalty } \\
\text { of employees }\end{array}$ & $0.70^{* *}$ & 6.95 & Supported \\
\hline $\begin{array}{l}\text { (H4)Barriers for CSR im- } \\
\text { plementation } \rightarrow \text { Loyalty of } \\
\text { employees }\end{array}$ & $-0.18^{* *}$ & -2.15 & $\begin{array}{l}\text { Negatively sup- } \\
\text { ported }\end{array}$ \\
\hline $\begin{array}{l}\text { (H5) Loyalty of employees } \rightarrow \\
\text { Business performance }\end{array}$ & $0.45^{* *}$ & 5.16 & Supported \\
\hline Note: $* *$ p $<0.001, *$ p $<0.05$, ns-non-significant & \\
\hline
\end{tabular}

The results of this study indicate the positive influence of CSR implementation on employee attitudes towards the overall company performance.

The research results depicted in Figure 2 and in Table 2 indicate a statistically significant effect regarding the understanding and adequate recognition of the purpose of implementing CSR on the selection of proper CSR activities $(\beta=0.33$ and $\mathrm{p}<0.01)$, thus confirming hypothesis H1. The statistical significance of the influence of recognizing the purpose of implementing CSR on the overcoming barriers to CSR implementation is low ( $\mathrm{p}>0.05)$. On the other hand, the correlation coefficient $\beta$ for this hypothesis (H2) is positive with the value 0.22 . This means that this hypothesis can be proved with some reservations, and that for an accurate estimation it would be necessary to test a larger sample. Hypothesis H3 indicates a statistically significant and high 
positive relationship between CSR activities and employee loyalty $(\beta=0.70, \mathrm{p}<0.01)$ and thus the hypothesis $\mathrm{H} 3$ can be accepted. Hypothesis H4, which states that the existence of barriers for the implementation of CSR does not have a positive influence on the loyalty of employees, is also accepted since the correlation between the factor representing barriers to the implementation of CSR and its influence on the loyalty of employees is negative with a statistical significance $(\beta=-0.18, p<0.01)$. Finally, the results of the research have shown that the loyalty of employees does have a positive effect on business performance. This was shown with a high statistical significance $(\beta=0.45, \mathrm{p}<0.01)$, thus confirming hypothesis $\mathrm{H} 5$.

To explain the variance in the total participation, i.e. how much of the variability of the dependent variable is explained by the independent variables, the coefficient of determination R 2 was used. The obtained value of R 2 was 0.406 , which suggests that $40.6 \%$ of the variance impact on CSR performance is a result of the joint influence of five latent determinants.

\section{DISCUSSION}

The essence of corporate social responsibility is that the companies consciously and voluntarily dedicate themselves to actions which exceed their primary activities aimed at increasing profits. Through CSR a company should strive to have a positive impact on the working, social and natural environment and to thus increase the possibility of gaining long term sustainability and a competitive edge.

In order to examine the impact of the most important elements of corporate social responsibility on company performance, the model proposed in this study included the measurement of certain factors considered to be essential for establishing positive relations between CSR and the company's performance. The proposed model showed a good fit to the collected data, with the findings revealing the relationships among the factors examined.

The company's management efforts in CSR implementation are dually recognized, both as an aspiration for a positive impact on society, employees, a sustainable economy, stakeholders, etc., as well as attempts to overcome barriers to socially responsible activities that result from a lack of information, resources or support. Our findings point out that a clearly defined motive, namely the purpose for implementing CSR, was highly recognized by employees, and that this influenced further activities the company introduced, a finding which proved H1. However, according to the results, this finding made no significant contribution to overcoming barriers to CSR implementation, in contrary to the assumption put forth in $\mathrm{H} 2$.

Previous studies have already dealt with the impact of CSR activities on employee behavior. Fortier (2013) showed that the more positive perception of the CSR activities of the company, the greater the employee job satisfaction. Similar results were obtained in a study where employees expressed their satisfaction and stronger job engagement as a consequence of CSR activities that their company oriented towards them. The survey findings actually reveal a high recognition of CSR efforts by employees. Further, the results showed a positive engagement of employees as a reaction to CSR, which demonstrated the validity of H3. Research carried out by Chaudhary (2017) also proved that a company's involvement in CSR significantly relates to positive employee attitude and engagement at work. 
The proposed measures for CSR showed that greater business performance is a direct consequence of employee loyalty, which confirmed H4 with high statistical indicators in the proposed structural model. These findings have been confirmed in other research, in which it was proved that CSR influences the financial results, but particularly sustainability, reputational and competitive value of the company (Carroll \& Shabana, 2010).

\section{CONCLUSION}

In order to propose a research framework for understanding CSR implementation and the related implications, several important issues were investigated, such as the purpose of implementation, CSR activities in companies, barriers, employee loyalty as well as the company performance. To establish the relations among the factors mentioned, a research model was proposed through which the proposed model was tested using SEM methodology, by which the reliability and validity of the measures was demonstrated.

The research results highlight the significance of a properly defined purpose of CSR implementation which is derived from management capabilities to well manage the company and build positive relationships in the company and with the surroundings. However, the results point out the importance of increasing employee awareness of the CSR activities that the company undertakes to gain greater loyalty. In general, a company will achieve better overall performance if stakeholders, employees among them, consider the company socially responsible. The aim of management, thus, should be to motivate new CSR-oriented activities that employees can identify as honest efforts rather than a marketing gimmick, and with that to increase the loyalty and level of alignment with company values. Finally, greater loyalty and engagement of employees improve the overall performance of the company.

This research has some limitations which can be the focus of future research. This research should be extended with a cross-cultural dimension by which the idiosyncrasies of countries will be taken into account. Likewise, other stakeholders should be examined in order to determine the overall level of awareness, recognition, and impact on the business results of CSR implementation.

\section{References}

1. Alhouti, S., Johnson, C., \& Holloway, B. (2016). Corporate social responsibility authenticity: Investigating its antecedents and outcomes. Journal of Business Research, 69 (3), 1242-1249. https://doi.org/10.1016/j.jbusres.2015.09.007

2. Ali, I., Rehman, K., Ali, S., Yousaf, J., \& Zia, M. (2010). Corporate social responsibility influences, employee commitment and organizational performance. African Journal of Business Management, 4 (12), 2796-2801.

3. Amodu, N. (2018). Corporate Social Responsibility as Catalyst for Development: Prospects and Challenges in Nigeria. Stakeholders, Governance and Responsibility, 207-228. http://dx.doi. org/10.1108/S2043-052320180000014010 
4. Behrend, T. S., Baker, B. A., \& Thompson, L. F. (2009). Effects of pro-environmental recruiting messages: The role of organizational reputations. Journal of Business and Psychology, 24 (3), 341-350. http://dx.doi.org/10.1007/s10869-009-9112-6

5. Brammer, S., He, H., \& Mellahi, K. (2014). Corporate Social Responsibility, Employee Organizational Identification, and Creative Effort. Group \& Organization Management, 40 (3), 323-352. http://dx.doi.org/10.1177/1059601114562246

6. Brammer, S., Millington, A., \& Rayton, B. (2007). The contribution of corporate social responsibility to organizational commitment. International Journal of Human Resource Management, 18 (10), 1701-1719. http://dx.doi.org/10.1080/09585190701570866

7. Branco, M. C., \& Rodrigues, L. L. (2006). Corporate Social Responsibility and ResourceBased Perspectives. Journal of Business Ethics, 69 (2), 111-132. http://dx.doi.org/10.1007/s10551006-9071-z

8. Calabrese, A., Costa, R., Menichini, T., Rosati, F., \& Sanfelice, G. (2013). Turning Corporate Social Responsibility driven Opportunities in Competitive Advantages: a Two-dimensional Model. Knowledge and Process Management (Print Edition), 20 (1), 50-58. http://dx.doi. $\operatorname{org} / 10.1002 / \mathrm{kpm} .1401$

9. Carroll, A. B., \& Shabana, K. M. (2010). The business case for corporate social responsibility: A review of concepts, research and practice. International Journal of Management Reviews, 12 (1), 85-105. https://doi.org/10.1111/j.1468-2370.2009.00275.x

10. Chaudhary, R. (2017). Corporate social responsibility and employee engagement: can CSR help in redressing the engagement gap? Social Responsibility Journal, 13 (2), 323-338. https://doi. org/10.1108/SRJ-07-2016-0115

11. Chen, E., \& Gavious, I. (2015). Does CSR have different value implications for different shareholders? Finance Research Letters, 14, 29-35. http://dx.doi.org/10.1016/j.frl.2015.07.001

12. Crowther, D., \& Aras, G. (2008). Corporate Social Responsibility (e-book). Retrieved October 9, 2018, from https://bookboon.com/premium/books/defining-corporate-socialresponsibility\#_=_

13. Dare, J. (2016). Will the Truth Set Us Free? An Exploration of CSR Motive and Commitment. Business and Society Review, 121 (1), 185-122. http://dx.doi.org/10.1111/basr.12082

14. De Roeck, K., El Akremic, A., \& Swaen, V. (2016). Consistency Matters! How and When Does Corporate Social Responsibility Affect Employees' Organizational Identification? Journal of Management Studies, 53 (7), 1141-1168. http://dx.doi.org/10.1111/joms.12216

15. Doh, P. J., Littell, B., \& Quigley, N. R. (2015). CSR and sustainability in emerging markets: Societal, institutional, and organizational influences. Organizational Dynamics, 44 (2), 112-120. http://dx.doi.org/10.1016/j.orgdyn.2015.02.005

16. Dos, A. (2017). Multi-criteria decision methods for CSR management -literature review. Managerial Economics, 18 (1), 63-86. http://dx.doi.org/10.7494/manage.2017.18.1.63

17. Dumitrescu, D., \& Simionescu, L. (2015). Empirical Research Regarding the Influence of Corporate Social Responsibility (CSR) Activities on Companies' Employees and Financial Performance. Economic Computation \& Economic Cybernetics Studies \& Research, 49 (3), 57-71. doi:10.3390/su10093141 
18. Fenwick, T., \& Bierema, L. (2008). Corporate Social Responsibility: Issues for Human Resource Development Professionals. International Journal of Training and Development, 12 (1), 24-35. http://dx.doi.org/10.1111/j.1468-2419.2007.00293.x

19. Fifka, M., \& Pobizhan, M. (2014). An institutional approach to corporate social responsibility in Russia. Journal of Cleaner Production, 82, 192-201. http://dx.doi.org/10.1016/j. jclepro.2014.06.091

20. Fortier, A. P. (2013). The Effects of Corporate Social Responsibility on Employees' Job Satisfaction: An Empirical Study with Cross Cultural Dimensions. Curtin University.

21. Freeman, E., \& Liedtka, J. (1997). Stakeholder Capitalism and the Value Chain. European Management Journal, 15 (3), 286-296. http://dx.doi.org/10.1016/S0263-2373(97)00008-X

22. Friedman, M. (1970). The Social Responsibility of Business is to Increase its Profits. The New York Times Magazine, 13 September, 122-126.

23. Galbreath, J. (2010). Drivers of corporate social responsibility: The role of formal strategic planning and firm culture. British Journal of Management, 21 (2), 511-525. https://doi. org/10.1111/j.1467-8551.2009.00633.x

24. Garavan, T., Heraty, N., Rock, A., \& Dalton, E. (2010). Conceptualizing the Behavioral Barriers to CSR and CS in Organizations: A Typology of HRD Interventions. Advances in Developing Human Resources, 12 (5), 587-613. http://dx.doi.org/10.1177/1523422310394779

25. Gill, R. (2015). Why the PR strategy of storytelling improves employee engagement and adds value to CSR: An integrated literature review. Public Relations Review, 41 (5), 662-674. http:// dx.doi.org/10.1016/j.pubrev.2014.02.012

26. Grover, P., Kumar Kar, A., \& Ilavarasan, P.V. (2019). Impact of corporate social responsibility on reputation-Insights from tweets on sustainable development goals by CEOs. International Journal of Information Management, 48, 39-52. http://dx.doi.org/10.1016/j.ijinfomgt.2019.01.009

27. Gürlek, M., \& Tuna, M. (2019). Corporate social responsibility and work engagement: Evidence from the hotel industry. Tourism Management Perspectives, 31, 195-208. http://dx.doi. org/10.1016/j.tmp.2019.05.004

28. Hanzaee, K., \& Rahpeima, A. (2013). Corporate Social Responsibility (CSR): A Scale Development Study in Iran. Research Journal of Applied Sciences, Engineering and Technology, 6 (9), 1513-1522. ISSN: 2040-7459; e-ISSN: 2040-7467

29. Houghton, S. M., Gabel, J. T. A., \& Williams, D. W. (2009). Connecting the Two Faces of CSR: Does Employee Volunteerism Improve Compliance? Journal of Business Ethics, 87 (4), 477-494. http://dx.doi.org/10.1007/s10551-008-9954-2

30. Jia, Y., Yan, J., Liu, T., \& Huang, J. (2019). How Does Internal and External CSR Affect Employees' Work Engagement? Exploring Multiple Mediation Mechanisms and Boundary Conditions. International Journal of Environmental Research and Public Health, 16 (14), 2476-2493. http://dx.doi.org/10.3390/ijerph16142476

31. Korschun, D., Bhattacharya, C. B., \& Swain, S. D. (2014). Corporate Social Responsibility, Customer Orientation, and the Job Performance of Frontline Employees. Journal of Marketing, 78 (3), 20-37. http://dx.doi.org/10.1509/jm.11.0245 
32. Lee, E., Park, S. Y., \& Lee, H. (2013). Employee perception of CSR activities: Its antecedents and consequences. Journal of Business Research, 66 (10), 1716-1724. http://dx.doi.org/10.1016/j. jbusres.2012.11.008

33. Lim, J. S., \& Greenwood, C. A. (2017). Communicating corporate social responsibility (CSR): Stakeholder responsiveness and engagement strategy to achieve CSR goals. Public Relations Review, 43 (4), 768-776. http://dx.doi.org/10.1016/j.pubrev.2017.06.007

34. Ling, Y. (2019). Cultural and contextual influences on corporate social responsibility. Cross Cultural \& Strategic Management, 26 (2), 290-310. http://dx.doi.org/10.1108/CCSM-02-20180024

35. López, M., Garcia, A., \& Rodriguez, L. J. (2007). Sustainable Development and Corporate Performance: A Study Based on the Dow Jones Sustainability Index. Journal of Business Ethics, 75 (3), 285-300. http://dx.doi.org/10.1007/s10551-006-9253-8

36. Matthiesen, M., \& Salzmann, A. (2017). Corporate social responsibility and firms' cost of equity: how does culture matter? Cross Cultural \& Strategic Management, 24 (1), 105-124. http:// dx.doi.org/10.1108/CCSM-11-2015-0169

37. Melo, T., \& Garrido-Morgado, A. (2012). Corporate reputation: A combination of social responsibility and industry. Corporate Social Responsibility and Environmental Management, 19 (1), 11-31. https://doi.org/10.1002/csr.260

38. Milošević, I., Živkovic, D., Manasijević, D., \&Nikolić, Đ. (2015). The effects of the intended behavior of students in the use of M-learning. Computers in Human Behavior, 51, 207-215. doi:10.1016/j.chb.2015.04.041

39. Öberseder, M., Schlegelmilch, B., \& Murphy, P. (2013). CSR practices and consumer perceptions. Journal of Business Research, 66 (10), 1839-1851. http://dx.doi.org/10.1016/j. jbusres.2013.02.005

40. Onkila, T. (2015). Pride or Embarrassment? Employees' Emotions and Corporate Social Responsibility. Corporate Social Responsibility and Environmental Management, 22 (4), 222-236. http://dx.doi.org/10.1002/csr.1340

41. Panwar, R., Paul, K., Nybakk, E., Hansen, E., \& Thompson, D. (2014). The legitimacy of CSR actions of publicly traded companies versus family-owned companies. Journal of Business Ethics, 125 (3), 481-496. http://dx.doi.org/10.1007/s10551-013-1933-6

42. Porter, M. E., \& Kramer, M. R. (2006). Strategy and society: The link between competitive advantage and corporate social responsibility. Harvard business review, 84 (12), 78-92.

43. Porter, M. E., \& Kramer, M. R. (2011). Create shared value, How to reinvent capitalism—and unleash a wave of innovation and growth. Harvard Business Review, 89, 63-77.

44. Prasad, A., \& Holzinger, I. (2013). Seeing through smoke and mirrors: A critical analysis of marketing CSR. Journal of Business Research, 66 (10), 1915-1921. http://dx.doi.org/10.1016/j. jbusres.2013.02.013

45. Raykov, T., \& Marcoulides, G. A. (2006). A first course in structural equation modeling. 2nd ed. Mahwah, NJ: Lawrence Erlbaum Associates, Publishers. 
46. Reverte, C., Gomez-Melero, E., \& Cegarra-Navarro, J. (2016). The influence of corporate social responsibility practices on organizational performance: evidence from Eco-Responsible Spanish firms. Journal of Cleaner Production, 112, 2870-2884. http://dx.doi.org/10.1016/j. jclepro.2015.09.128

47. Rupp, D. E., Shao, R., Thornton, M. A., \& Skarlicki, D. P. (2013). Applicants' and employees' reactions to corporate social responsibility: the moderating effects of first-party justice perceptions and moral identity. Personnel Psychology, 66 (4), 895-933. http://dx.doi.org/10.1111/ peps. 12030

48. Stoian, C., \& Zaharia, R. (2012). CSR development in post-communist economies: employees' expectations regarding corporate socially responsible behaviour - the case of Romania. Business Ethics: A European Review, 21 (4), 380-401. http://dx.doi.org/10.1111/beer.12000

49. Story, J., \& Neves, P. (2015). When corporate social responsibility (CSR) increases performance: exploring the role of intrinsic and extrinsic CSR attribution. Business Ethics: $A$ European Review, 24 (2), 111-124. http://dx.doi.org/10.1111/beer.12084

50. Su, L., \& Swanson, S. R. (2019). Perceived corporate social responsibility's impact on the well-being and supportive green behaviors of hotel employees: The mediating role of the employee-corporate relationship. Tourism Management, 72, 437-450. http://dx.doi.org/10.1016/j. tourman.2019.01.009

51. Sweeney, L. (2007). Corporate social responsibility in Ireland: barriers and opportunities experienced by SMEs when undertaking CSR. Corporate Governance, 7 (4), 516-523. http:// dx.doi.org/10.1108/14720700710820597

52. Taras, V., Steel, P., \& Kirkman, B. L. (2011). Three decades of research on national culture in the workplace: Do the differences still make a difference? Organizational Dynamics, 40 (3), 189-198. https://doi.org/10.1016/j.orgdyn.2011.04.006

53. Thao, L. H. H., Anh, D. N. P., \& Velencei, J. (2019). Measuring corporate social performance. Serbian Journal of Management, 14 (1), 193-204. https://doi.org/10.5937/sjm14-18009

54. Tkalac Verčič, A., \& Sinčić Ćorić, D. (2018). The relationship between reputation, employer branding and corporate social responsibility. Public Relations Review, 44 (4), 444-452. https:// doi.org/10.1016/j.pubrev.2018.06.005

55. Turker, D. (2009). How Corporate Social Responsibility Influences Organizational Commitment. Journal of Business Ethics, 89 (2), 189-204. https://doi.org/10.1007/s10551-0089993-8

56. Udo, G. J., Bagchi, K. K., \& Kir, P. J. (2010). An assessment of customers' e-service quality perception, satisfaction and intention. International Journal of Information Management, 30 (6), 481-492. http://dx.doi.org/10.1016/j.ijinfomgt.2010.03.005

57. Vlachos, P., Panagopoulos, N., \& Rapp, A. (2014). Employee judgments of and behaviors toward corporate social responsibility: A multi-study investigation of direct, cascading, and moderating effects. Journal of Organizational Behavior, 35 (7), 990-1017. http://dx.doi. org/10.1002/job.1946

58. Wu, Y. (2013). A Survey-Based Discussion on Perception and Attitude towards CSR in China. Creative Education, 4 (4), 267-272. http://dx.doi.org/10.4236/ce.2013.44040 
59. Yeh, S., Chen, Y., Kao, Y., \& Wu, S. (2014). Obstacle factors of corporate social responsibility implementation: Empirical evidence from listed companies in Taiwan. The North American Journal of Economics and Finance, 28 (3), 313-326. http://dx.doi.org/10.1016/j.najef.2014.03.011

\section{Contact information}

Ms. Andelka Stojanovic, Ph.D. candidate

University of Belgrade

Technical Faculty in Bor

Engineering Management Department

Serbia

E-mail:anstojanovic@tfbor.bg.ac.rs

ORCID:0000-0001-7254-4646

Associate prof. Isidora Milosevic, Ph.D.

University of Belgrade

Technical Faculty in Bor

Engineering Management Department

Serbia

E-mail:imilosevic@tfbor.bg.ac.rs

ORCID:0000-0002-9242-2774

Assistant prof. Sanela Arsic, Ph.D.

University of Belgrade

Technical Faculty in Bor

Engineering Management Department

Serbia

E-mail: saarsic@tfbor.bg.ac.rs

ORCID:0000-0002-1957-566X

Prof. Snezana Urosevic, Ph.D.

University of Belgrade

Technical Faculty in Bor

Engineering Management Department

Serbia

E-mail:surosevic@tfbor.bg.ac.rs

ORCID:0000-0002-6647-0449

Prof. Ivan Mibajlovic, Ph.D.

University of Belgrade

Technical Faculty in Bor

Engineering Management Department

Serbia

E-mail:imilosevic@tfbor.bg.ac.rs

ORCID:0000-0002-9489-8207 


\section{Appendix 1}

Questionnaire regarding the attitude of respondents to corporate social responsibility and its influence on the business performance of the company

Factor F1 - The purpose of implementation of CSR: I believe that CSR should be implemented with the purpose to:

Q1. Improvement of the level of awareness in the company.

Q2. Enhancement of motivation and engagement of employees.

Q3. Improvement of the customers' loyalty.

Q4. Improvement of the image of the company.

Q5. Better conditions for attracting qualified employees.

Factor F2 - CSR activities: According to your opinion, to what extend is your company involved in the following CSR activities?

Q1. Activities for development of employees (listening to employees' opinions and engagement of employees, training focused on the fight against harassment and violence, skills development...).

Q2. Activities for employees' stimulation (creative activities to avoid dismissals in economically critical situations, for example, reduced working hours).

Q3. Stimulating sustainable local economy and community activities (supporting local events, investment in the development of the municipal sector, charity, partnerships for social investment, philanthropy, volunteering).

Q4. Stakeholder engagement in the decision making process (actively engaging employees, customers, suppliers and the community).

Q5. Measures to protect the environment.

Factor F3 - Barriers for the implementation of CSR: Barriers/threats your company has faced by behaving in a socially responsible manner

Q1. Lack of information on CSR

Q2. Lack of human resources/capacities

Q3. Lack of financial resources

Q4. Absence of state/government support

Q5. Absence of public support/pressure

Q6. Lack of know-how for the implementation of CSR principles

Q7. Lack of motivation among employees 
Factor F4- Loyalty of employees: Employee loyalty and satisfaction

Q1. How happy are you at work?

Q2. How would you rate your organization's culture?

Q3. How valued do you feel at work?

Q4. How would you rate your colleagues and team members?

Q5. How would you rate the performance of your direct supervisor?

Q6. How much opportunity for professional growth do you have in the organization?

Q7. I am inspired to meet my goals at work.

Q8. I feel completely involved in my work.

Q9. I feel happy when I go to my work.

Q10. How likely is it that you would recommend your organization's products or services to a friend or colleague?

Q11. How well, do you think, the company services its customers?

Q12. Do you talk about your company with pleasure or sometimes with proud outside of your working place with other people, with your neighbors or at events?

Factor F5 - Business performance: Please rate the influence of applied CSR activities on the following business performances of your company.

Q1. Sales (long-term increase)

Q2. Profit

Q3. Image of the company

Q4. Customer loyalty

Q5. Better conditions to attract qualified employees

Q6. Employee loyalty/engagement

Q7. Trust (employees, customers...)

Q8. Cost reduction

Q9. Marketing 